\title{
A Monitoring of Allantoin, Uric Acid, and Malondialdehyde Levels in Plasma and Erythrocytes After Ten Minutes of Running Activity
}

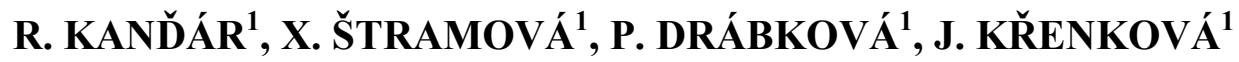 \\ ${ }^{1}$ Department of Biological and Biochemical Sciences, Faculty of Chemical Technology, University \\ of Pardubice, Pardubice, Czech Republic
}

Received November 12, 2013

Accepted May 16, 2014

On-line August 26, 2014

\begin{abstract}
Summary
Uric acid is the final product of human purine metabolism. It was pointed out that this compound acts as an antioxidant and is able to react with reactive oxygen species forming allantoin. Therefore, the measurement of allantoin levels may be used for the determination of oxidative stress in humans. The aim of the study was to clarify the antioxidant effect of uric acid during intense exercise. Whole blood samples were obtained from a group of healthy subjects. Allantoin, uric acid, and malondialdehyde levels in plasma and erythrocytes were measured using a HPLC with UV/Vis detection. Statistical significant differences in allantoin and uric acid levels during short-term intense exercise were found. Immediately after intense exercise, the plasma allantoin levels increased on the average of $200 \%$ in comparison to baseline. Plasma uric acid levels increased slowly, at an average of $20 \%$. On the other hand, there were no significant changes in plasma malondialdehyde. The results suggest that uric acid, important antioxidant, is probably oxidized by reactive oxygen species to allantoin. Therefore allantoin may be suitable candidate for a marker of acute oxidative stress.
\end{abstract}

\section{Key words}

Allantoin • Uric acid • Oxidative stress • Antioxidants • Shortterm intense exercise

\section{Corresponding author}

R. Kand'ár, Department of Biological and Biochemical Sciences, Faculty of Chemical Technology, University of Pardubice, Studentska 573, 53210 Pardubice, Czech Republic. Fax: +420 466037068. E-mail: roman.kandar@upce.cz

\section{Introduction}

Reactive oxygen species (ROS) have recently become a significant research subject. Many scientists are seeking to assess their role in physiological and mainly pathological processes. This is why ROS have become the subject of intense medical research and its results are slowly being applied in medical practice. There are currently a number of methods for evaluating oxidative stress (Giustarini et al. 2009, Kaneko et al. 2012, Chung and Benzie 2013). Monitoring radical reactions in the body is difficult and therefore usually substances produced by the effects of free radicals or compounds with antioxidant capabilities are determined instead. Indicators of oxidative stress can be measured in various body fluids or tissues (Abdul-Rasheed et al. 2010, Schrag et al. 2013).

An important antioxidant is uric acid (UA), traditionally thought to be only the end product of purine degradation in humans with no other physiological function. The formation of UA can be accompanied by the emergence of ROS (Becker 1993). Most other mammals are able to further degrade UA to allantoin. UA is converted to allantoin by uricase, but humans have several "nonsense" mutations in the gene encoding uricase, and therefore this gene is not expressed, although it is still present (Yeldandi et al. 1992).

Although the human body does not contain an active uricase enzyme, ROS may non-enzymatically change the UA to allantoin, parabanic acid, oxaluric acid, oxonic acid, cyanuric ucid and urea (Volk et al. 1989, Kaur and Halliwell 1990, Hicks et al. 1993). Allantoin is

PHYSIOLOGICAL RESEARCH • ISSN 0862-8408 (print) • ISSN 1802-9973 (online)

(c) 2014 Institute of Physiology v.v.i., Academy of Sciences of the Czech Republic, Prague, Czech Republic

Fax +420 241062 164, e-mail: physres@biomed.cas.cz, www.biomed.cas.cz/physiolres 
the most prevalent and its level in body fluids is thus regarded as an indicator of an increased production of ROS (Tolun et al. 2010, 2012, Il'yasova et al. 2012, Turner et al. 2012, Chung and Benzie 2013). The human body carefully protects its UA reserves. UA is completely filtered in kidneys, but more than $90 \%$ is resorbed into the blood in the tubules. Such a treatment of UA is therefore not consistent with the theory that UA is only the end product of purine metabolism (Becker et al. 1991).

The antioxidant importance of UA lies not only in the fact that it is found in all body fluids and tissues, but also that its plasma concentration $(150-450 \mu \mathrm{mol} / \mathrm{l})$ is much higher than that of other antioxidants (Becker et al. 1991, Becker 1993). One-electron oxidation of UA with strong oxidants creates a urate anion radical that is efficiently taken up by ascorbic acid (Maples and Mason 1988, Becker 1993). More important is the ability of UA to create stable coordination complexes with iron ions. Through this mechanism, UA inhibits the Fenton reaction (giving rise to the highly reactive hydroxyl radical). Inhibition of the formation of the hydroxyl radical is considered the most important antioxidant effect of UA (Ames et al. 1981). UA itself also reacts with a hydroxyl radical and hypochlorous acid, and inhibits the formation of oxo-heme oxidants (Maples and Mason 1988, Becker et al. 1991).

The role of ROS in skeletal muscle damage after strenuous physical activity has been discussed a great deal recently. Physical load significantly increases the production of ROS; their destructive effects can then influence sports performance and contribute to the onset of muscle fatigue ( $\mathrm{Ji}$ 1999, Castrogiovanni and Imbesi 2012, Gravier et al. 2013, Ramos et al. 2013).

The level of ROS production depends on the duration, intensity and type of physical activity, is highly variable because it depends on physical condition, diet, genetic and various other factors.

The aim of this work is to monitor the levels of allantoin, UA, and malondialdehyde (MDA) in plasma and erythrocytes of volunteers burdened with strenuous exercise, when a significant production of ROS is expected.

\section{Materials and Methods}

\section{Reagents and chemicals}

Allantoin, ortho-phosphoric acid, sodium hydroxide, sodium chloride, hydrochloric acid, phosphate buffer $\quad(8.3 \mathrm{mmol} / \mathrm{l}, \quad \mathrm{pH} 7.2)$, sodium dihydrogenphosphate, sodium hydrogenphosphate, metaphosphoric acid (MPA), uric acid, 1,1,3,3tetramethoxypropane (TMP), ethylenediaminetetraacetic acid (EDTA), acetic acid, 2,4-dinitrophenylhydrazine (DNPH) and 2-thiobarbituric acid (TBA) were obtained from Sigma Chemical Company. AG 1-X8 Resin, 100-200 mesh, chloride form, was purchased from Bio-Rad Laboratories (Hercules, CA, USA), HPLCgradient grade acetonitrile (ACN) and methanol was from Merck (Darmstadt, Germany). Lyophilized UA, creatinine and lactate mixed standard (CHEM I Calibrator, Level 3, Lot 4HD007) and liquid assayed chemistry UA, creatinine and lactate control (Dade TRULiquid Moni-Trol Control, Level 1, Lot TLM0503-1 and Level 2, Lot TLM0503-2) were from Dade Behring (Newark, DE, USA). All other chemicals were of analytical grade. Because UA is slightly soluble in alkaline solution, but an alkali environment leads to degradation of UA into allantoin, a commercial lyophilized standard was used.

\section{Instrumentation}

Chromatographic analyses were performed with a liquid chromatograph Shimadzu (Kyoto, Japan) equipped with a LC-10AD solvent delivery system, a SIL-10AD autosampler, a CTO-10AS column oven, a SPD-10A variable wavelength spectrophotometric detector, and a SCL-10A system controller. Data were collected digitally using the chromatography software Clarity (DataApex, Prague, Czech Republic).

Spectrophotometric analyses were carried out on a Shimadzu (Kyoto, Japan) UV-1700 PharmaSpec spectrophotometer.

\section{Subjects}

A total of 30 healthy subjects (15 women aged 22-36 years, mean age 29 years, and 15 men aged 21-40 years, mean age 31 years) were included in the study (for the group characteristics, see Table 1). None of the studied subjects exhibited any renal, hepatic, gastrointestinal, pulmonary or oncological diseases. They were considered healthy according to a physical examination and routine laboratory tests. All study participants were informed of all risks and gave written informed consent to participate in this study, which was approved by the Hospital Committee on Human Research (Regional Hospital of Pardubice, Czech Republic) according to the Helsinki Declaration. 
Table 1. Group characteristics.

\begin{tabular}{|c|c|c|c|}
\hline & Women & Men & $\mathbf{P}$ \\
\hline Age (years) & $29 \pm 4$ & $31 \pm 5$ & - \\
\hline$B M I\left(\mathrm{~kg} / \mathrm{m}^{2}\right)$ & $22.7 \pm 3.8$ & $23.4 \pm 4.1$ & - \\
\hline Hemoglobin $(g / l)$ & $139 \pm 7$ & $151 \pm 9$ & $* * *$ \\
\hline$P_{-} A L A(\mu \mathrm{mol} / \mathrm{l})$ & $1.8 \pm 0.5$ & $2.0 \pm 0.9$ & - \\
\hline RBC_ALA (nmol/g Hb) & $17 \pm 5$ & $19 \pm 7$ & - \\
\hline$P_{-} U A(\mu \mathrm{mol} / \mathrm{l})$ & $220 \pm 60$ & $315 \pm 68$ & $* * *$ \\
\hline$R B C \_U A(\mathrm{nmol} / \mathrm{g} \mathrm{Hb})$ & $74 \pm 16$ & $83 \pm 26$ & - \\
\hline$P_{-} M D A(\mu \mathrm{mol} / \mathrm{l})$ & $0.79 \pm 0.21$ & $0.88 \pm 0.29$ & - \\
\hline RBC_MDA (nmol/g Hb) & $67 \pm 18$ & $75 \pm 24$ & - \\
\hline$P \_$Lactate $(\mathrm{mmol} / \mathrm{l})$ & $1.2 \pm 0.7$ & $1.4 \pm 0.9$ & - \\
\hline
\end{tabular}

P - Plasma, RBC - Red Blood Cells, ALA - Allantoin, UA - Uric Acid, MDA - Malondialdehyde, Hb - Hemoglobin, BMI - Body Mass Index. $* * * \mathrm{P}<0.001$.

The subjects were trained in different kinds of sports such as football, basketball, swimming, cycling, badminton and squash. All volunteers attended 10-min run at a speed of about $9.6 \pm 0.3 \mathrm{~km}$ per hour on flat ground (4 x $400 \mathrm{~m}$ oval track; $1600 \pm 50 \mathrm{~m}$ ).

\section{Whole blood samples collection}

Peripheral venous blood samples were obtained from each volunteer immediately before starting the experiment (before intense exercise), immediately after intense exercise (10-min run) and $60 \mathrm{~min}$ after intense exercise. Blood $(6 \mathrm{ml})$ was collected into plastic tubes with EDTA (The Vacuette Detection Tube, No. 456023, Greiner Labortechnik Co., Kremsmünster, Austria). Plasma was separated from red blood cells by centrifugation $\left(1700 \mathrm{x} \mathrm{g}, 15 \mathrm{~min}, 8^{\circ} \mathrm{C}\right)$ and immediately stored at $-80^{\circ} \mathrm{C}$. Erythrocytes were washed four times by isotonic solution ( $0.85 \%$ sodium chloride) and after their lysis by ice-cold deionized water immediately stored at $-80{ }^{\circ} \mathrm{C}$.

\section{Determination of allantoin}

Plasma and erythrocyte allantoin was measured as previously reported (Kand'ár et al. 2006, Kand'ár and Záková 2008a). Briefly, $300 \mu \mathrm{l}$ of standard solution, plasma or red blood cells hemolysate were pipetted into a well-capped $1.5 \mathrm{ml}$ polypropylene (PP) tube (Thermo Fisher Scientific, Pardubice, Czech Republic). $600 \mu$ of cold ACN were added and the solution was vortexed for $60 \mathrm{~s}$, incubated $\left(4{ }^{\circ} \mathrm{C}, 10 \mathrm{~min}\right)$, and centrifuged $(22000 \mathrm{x}$ $\left.\mathrm{g}, 4{ }^{\circ} \mathrm{C}, 10 \mathrm{~min}\right)$. Sediment was re-extracted with $600 \mu \mathrm{l}$ of cold ACN/0.01 mol/1 $\mathrm{H}_{3} \mathrm{PO}_{4}, \quad$ pH 7.3 (1:1). The combined supernatants were immediately applied to solid phase extraction (SPE) column (AG 1-X8 anionexchange resin). A purified sample was evaporated to dryness under nitrogen (Linde Gas, Prague, Czech Republic) at $60{ }^{\circ} \mathrm{C}$. Dry residue was dissolved in $200 \mu \mathrm{l}$ of $0.1 \mathrm{~mol} / 1 \mathrm{NaOH}$ and incubated $\left(100{ }^{\circ} \mathrm{C}, 20 \mathrm{~min}\right)$. After cooling, $300 \mu \mathrm{l}$ of $1.5 \mathrm{mmol} / 1 \mathrm{DNPH}$ in $2.5 \mathrm{~mol} / 1 \mathrm{HCl}$ were added and the solution was incubated $\left(50{ }^{\circ} \mathrm{C}\right.$, $50 \mathrm{~min}$ ). The reaction mixture was then filtered through a nylon filter (pore size $0.20 \mu \mathrm{m}, 4 \mathrm{~mm}$ diameter; Supelco, Bellefonte, PA, USA) and transferred into $1.0 \mathrm{ml}$ amber vial. $20 \mu \mathrm{l}$ was injected onto a HPLC equipped with a guard column Discovery C18, $20 \mathrm{x}$ $4 \mathrm{~mm}$ i.d., $5 \mu \mathrm{m}$, an analytical column Discovery C18, 150 x $4 \mathrm{~mm}$ i.d., $5 \mu \mathrm{m}$ (Supelco), and a UV/Vis detector. For the gradient elution, two mobile phases were used: A $-5 \%$ ACN in $8.3 \mathrm{mmol} / 1$ phosphate buffer $(\mathrm{v} / \mathrm{v})$, $\mathrm{pH} 6.1 \pm 0.1$, and $\mathrm{B}-50 \% \mathrm{ACN}$ in $8.3 \mathrm{mmol} / \mathrm{l}$ phosphate buffer $(\mathrm{v} / \mathrm{v}), \mathrm{pH} 6.1 \pm 0.1$. The flow rate was kept constant at $0.5 \mathrm{ml} / \mathrm{min}$, and the separation ran at $37^{\circ} \mathrm{C}$. Optimum response of glyoxylate-2,4-dinitrophenylhydrazone derivative, corresponding to allantoin, was observed when the wavelength was set to $360 \mathrm{~nm}$. The analytical parameters of plasma and erythrocyte allantoin analysis were as follows: intra-assay with coefficient of variation (CV) $5.7 \%(n=10)$ and $\mathrm{CV} 3.8 \%(n=10)$, inter-assay with $\mathrm{CV} 8.3 \%(\mathrm{n}=12)$ and $\mathrm{CV} 6.6 \% \quad(\mathrm{n}=12)$, and recovery $94.1 \%(n=5)$ and $97.2 \%(n=5)$. The calibration curve was linear in the whole range tested $(0.5-50.0 \mu \mathrm{mol} / \mathrm{l})$. The lowest concentration that could be quantified with acceptable accuracy and precision was $0.5 \mu \mathrm{mol} / 1$ ( $6.0 \mathrm{pmol} /$ inject). The limit of detection, defined as a signal-to noise $(\mathrm{S} / \mathrm{N})$ ratio of $3: 1$, was $0.15 \mu \mathrm{mol} / 1$ ( $1.8 \mathrm{pmol} /$ inject $)$.

\section{Determination of uric acid}

Plasma and erythrocyte UA was measured as previously reported (Kand'ár and Záková 2008b). Briefly, $200 \mu \mathrm{l}$ of standard solution, plasma or red blood cells hemolysate were pipetted into a well-capped $1.5 \mathrm{ml} \mathrm{PP}$ tube. $400 \mu \mathrm{l}$ of cold $10 \% \mathrm{MPA}$ were added and the solution was vortexed for $60 \mathrm{~s}$, incubated $\left(4^{\circ} \mathrm{C}, 10 \mathrm{~min}\right)$, and centrifuged $\left(22000 \mathrm{x} \mathrm{g}, 4^{\circ} \mathrm{C}, 10 \mathrm{~min}\right)$. Supernatants were filtered through a nylon filter (pore size $0.20 \mu \mathrm{m}$, $4 \mathrm{~mm}$ diameter) and transferred into $1.0 \mathrm{ml}$ amber vials. $10 \mu \mathrm{l}$ was injected onto a HPLC system. The chromatography analysis of UA was accomplished using an isocratic elution on a Discovery C18, 250 x 4 mm i.d., 
$5 \mu \mathrm{m}$, analytical column fitted with a Discovery C18, $20 \times 4 \mathrm{~mm}$ i.d., $5 \mu \mathrm{m}$, guard column at $25^{\circ} \mathrm{C}$. The mobile phase was a mixture of methanol and $25 \mathrm{mmol} / \mathrm{l}$ sodium dihydrogenphosphate $(\mathrm{v} / \mathrm{v}), \mathrm{pH} 4.8 \pm 0.1$. The flow rate was kept constant at $0.5 \mathrm{ml} / \mathrm{min}$. Optimum response of UA was observed when wavelength was set to $292 \mathrm{~nm}$.

The analytical parameters of plasma and erythrocyte UA analysis were as follows: intra-assay with CV $2.3 \%(n=10)$ and CV $3.8 \%(n=10)$, inter-assay with CV $7.7 \%(n=12)$ and CV $9.2 \%(n=12)$, and recovery $98.1 \%(n=5)$ and $94.3 \%(n=5)$. The calibration curve was linear in the whole range tested for plasma (20-1000.0 $\mu \mathrm{mol} / \mathrm{l})$ and erythrocyte lysate (1-100 $\mu \mathrm{mol} / \mathrm{l})$. The lowest concentration that could be quantified with acceptable accuracy and precision was $1.0 \mu \mathrm{mol} / 1$ (3.3 pmol/inject). The limit of detection, defined as a signal-to noise $(\mathrm{S} / \mathrm{N})$ ratio of $3: 1$, was $0.3 \mu \mathrm{mol} / 1$ (1.0 pmol/inject).

\section{Determination of malondialdehyde}

Plasma and erythrocyte MDA was measured as previously reported (Kand'ár et al. 2002). Briefly, $200 \mu 1$ of standard solution (MDA obtained by acid hydrolysis of TMP), plasma or red blood cells hemolysate were pipetted into a well-capped $2.0 \mathrm{ml}$ amber glass tube, $600 \mu 1$ of $0.1 \%$ EDTA and $200 \mu 1$ of $28 \mathrm{mmol} / 1 \mathrm{TBA}$ in $8.75 \mathrm{~mol} / 1$ acetic acid were added and the solution was vortexed for $60 \mathrm{~s}$ and incubated $\left(100{ }^{\circ} \mathrm{C}, 60 \mathrm{~min}\right)$. After cooling, $500 \mu \mathrm{l}$ of cold $\mathrm{n}$-butanol were then added, the solution was vortexed for $30 \mathrm{~min}$, and centrifuged (2910 x g, $4{ }^{\circ} \mathrm{C}, 20 \mathrm{~min}$ ). The upper n-butanol layer was filtered through a nylon filter (pore size $0.20 \mu \mathrm{m}, 4 \mathrm{~mm}$ diameter) and transferred into $1.0 \mathrm{ml}$ amber vial. $10 \mu \mathrm{l}$ was injected onto a HPLC equipped with a guard column LiChroCart 4 x $4 \mathrm{~mm}$, Purospher Star RP-18e, $5 \mu \mathrm{m}$, an analytical column LiChroCart $125 \times$ x , Purospher Star RP-18e, $5 \mu \mathrm{m}$ (Merck, Darmstadt, Germany), and a UV/Vis detector. For the isocratic elution of $\mathrm{MDA}(\mathrm{TBA})_{2}$ derivative, a mixture of $35 \%$ methanol in $8.3 \mathrm{mmol} / 1$ phosphate buffer $(\mathrm{v} / \mathrm{v}), \mathrm{pH} 7.2$, was used as a mobile phase. The flow rate was kept constant at $0.5 \mathrm{ml} / \mathrm{min}$, and the separation ran at $37^{\circ} \mathrm{C}$. Optimum response of $\mathrm{MDA}(\mathrm{TBA})_{2}$ derivative was observed when the wavelength was set to $532 \mathrm{~nm}$. The analytical parameters of plasma and erythrocyte MDA analysis were as follows: intra-assay with CV $5.2 \%(\mathrm{n}=10)$ and CV $5.7 \%(n=10)$, inter-assay with CV $8.4 \%(n=12)$ and CV $9.1 \%(n=12)$ and recovery $96.6 \%(n=5)$ and $95.4 \%$ $(n=5)$. The calibration curve was linear in the whole range tested $(0.2-10.0 \mu \mathrm{mol} / 1)$. The lowest concentration that could be quantified with acceptable accuracy and precision was $0.2 \mu \mathrm{mol} / 1$ ( $0.80 \mathrm{pmol} / \mathrm{inject})$. The limit of detection, defined as a signal-to noise $(\mathrm{S} / \mathrm{N})$ ratio of $3: 1$, was $0.06 \mu \mathrm{mol} / 1(0.24 \mathrm{pmol} / \mathrm{inject})$.

\section{Determination of lactate}

Lactate in the plasma was measured with the set Lactate Flex ${ }^{\circledR}$ by standard procedure using an automatic biochemistry analyzer Dimension ${ }^{\circledR} \operatorname{RxL}$ Max ${ }^{\circledR}$ (Siemens Healthcare Diagnostic Ltd., Deerfield, IL, USA).

\section{Determination of hemoglobin}

Hemoglobin in the red blood cells hemolysate was measured with a HEMOGLOBIN set (Lachema, Brno, Czech Republic). Briefly, $5.00 \mathrm{ml}$ of working solution $(0.8 \mathrm{mmol} / \mathrm{l}$ potassium cyanide and $0.5 \mathrm{mmol} / 1$ potassium ferricyanide in $1.1 \mathrm{mmol} / \mathrm{l}$ N-methyl-Dglucamine buffer, $\mathrm{pH} 8.3$ ) were mixed with $0.02 \mathrm{ml}$ of the red blood cells hemolysate sample or standard solution in a test tube. After incubation (room temperature, $10 \mathrm{~min}$ ), the absorbance was read at $543 \mathrm{~nm}$ against the working solution on a UV-1700 PharmaSpec spectrophotometer.

\section{Statistical analysis}

Data were analyzed using the Sigmastat version 3.5 (Systat Software Inc., Point Richmond, CA, USA) and the STATISTICA version 12 (StatSoft CR s.r.o., Prague, Czech Republic). The data are presented as median $\pm \mathrm{IQR}$ (interquartile range). Differences between women and men were analyzed using the Mann-Whitney Rank Sum Test. A two-factor analysis of variance (ANOVA) was performed to investigate of changes in levels of plasma and red blood cells hemolysate allantoin, UA, MDA and plasma lactate as a function of time (immediately after exercise and one hour after exercise) and age. Post-hoc comparisons were made using the Holm Sidak test, with alpha set at 0.05 . The Holm Sidak test can be used for both pairwise comparisons and comparisons versus a control group. It is more powerful than Tukey and Bonferroni test, and, consequently, it is able to detect differences that these tests do not. It is recommended as the first-line procedure for pairwise comparison testing.

\section{Results}

In this study, we monitored the levels of allantoin and UA in the plasma and erythrocytes of 
volunteers after a 10-min running activity. In addition, we determined the plasma and erythrocyte levels of MDA, a classic indicator of oxidative stress, and plasma lactate concentration, an appropriate indicator of muscle load and anaerobic glycolysis.

We found a significant increase in the plasma concentration of allantoin immediately after the 10-min running activity, on average by $200 \%$. After an hour of rest, allantoin levels almost returned to their initial value (Fig. 1A). Significant increase in the erythrocyte concentration of allantoin was observed too, and this trend continued during the first hour after the workout. This is a completely different process than that in plasma (Fig. 1B). Allantoin is a highly polar substance, thus is completely, just like for example creatinine, practically totally eliminated via the kidneys (Lagendijk et al. 1995, Berthemy et al. 1999). Therefore, after one hour, we found allantoin in plasma at virtually the same levels as before the running activity. Allantoin from erythrocytes is apparently released very slowly into plasma. It is possible that in erythrocytes the oxidative stress during physical load is more intensive and lasts longer.
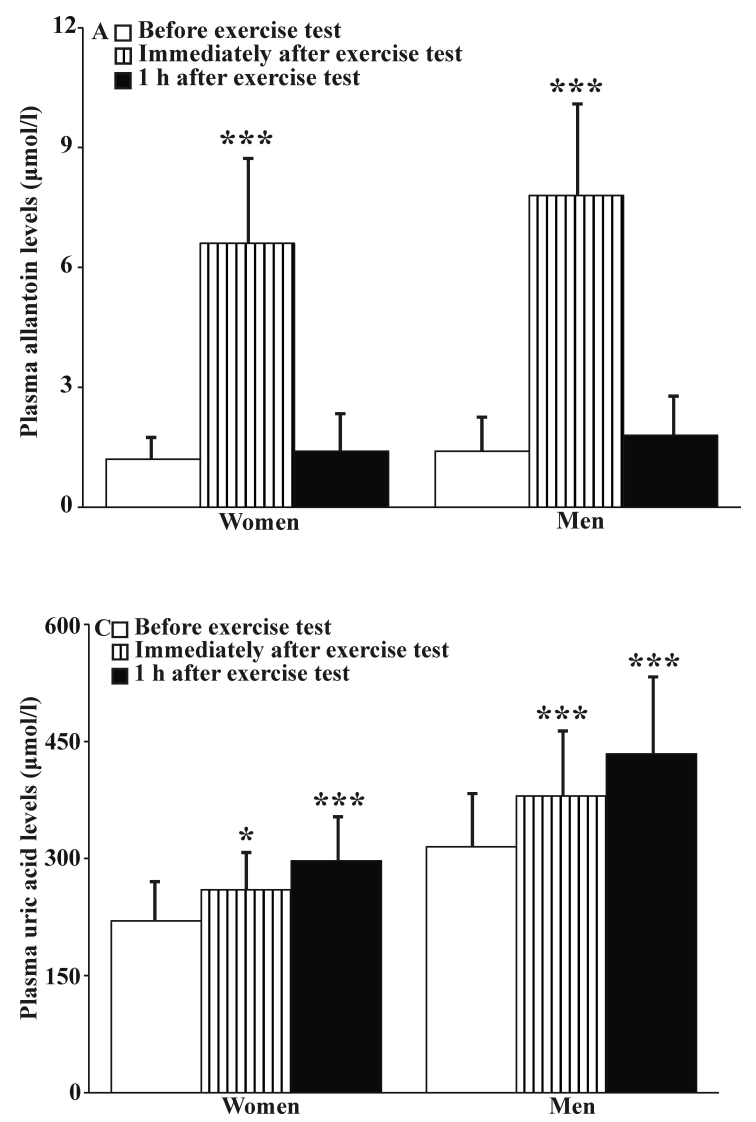

Changes in the plasma levels of UA had a completely different course than the changes in the levels of allantoin. The concentration of UA reached its maximum one hour after the end of the workout (Fig. 1C). The erythrocyte level of uric acid immediately after running activity was significant increased, after an hour of rest a decline was observed (Fig. 1D). This corresponds to an increased level of erythrocyte allantoin, an oxidative product of UA. It is known that the level of UA in plasma increases during physical exertion. This is probably also partially caused by an inhibition of the renal clearance of UA with lactate (Fig. 2C), which is accumulated in plasma during exercise (Hellsten et al. 2001). Another possible mechanism for increasing the concentration of UA in plasma is the metabolic conversion of hypoxanthine to UA in hepatocytes. The resulting UA is then used as an antioxidant in myocytes and erythrocytes exposed to oxidative stress, resulting in increased levels of allantoin. The enrichment of muscles and erythrocytes with UA during exercise could therefore mean an increase in the availability of antioxidant substances stimulated by the increasing production of ROS.
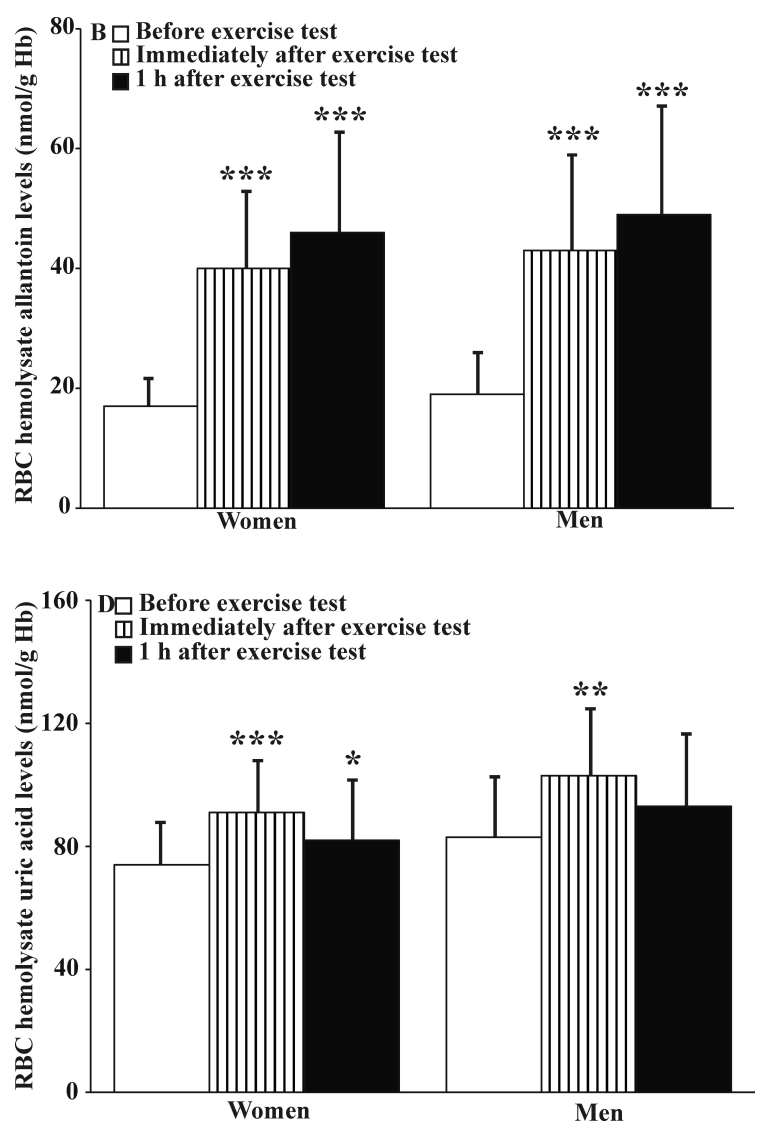

Fig. 1. Plasma allantoin (A), red blood cells hemolysate allantoin (B), plasma uric acid (C), and red blood cells hemolysate uric acid (D) levels in healthy subjects (15 women and 15 men; duplicate assays) before running activity, immediately after running activity and $1 \mathrm{~h}$ after running activity. The results are expressed as median \pm IQR (interquartile range). ${ }^{*} \mathrm{p}<0.05 ; * * \mathrm{p}<0.01 ; * * * \mathrm{p}<0.001$ (compared to levels before running activity). 

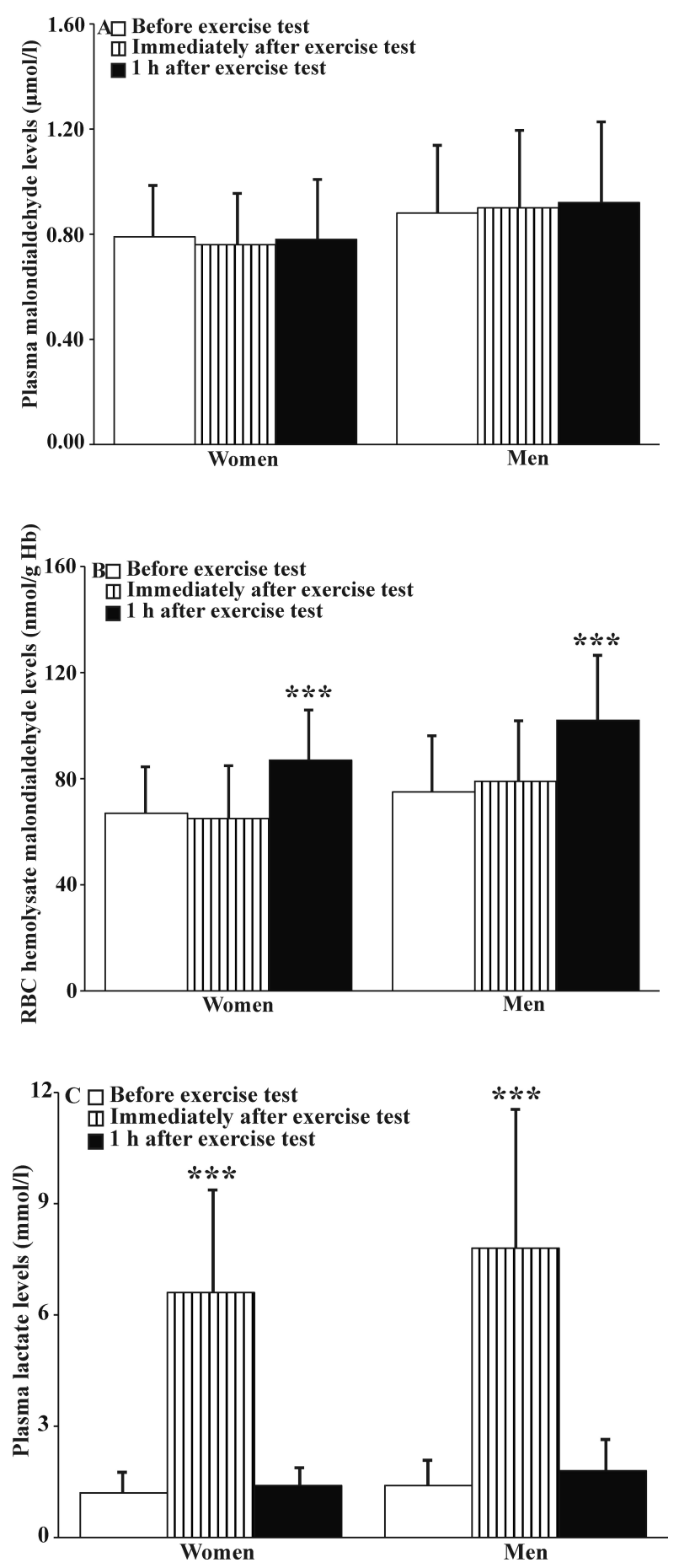

Fig. 2. Plasma malondialdehyde (A), red blood cells hemolysate malondialdehyde (B), and plasma lactate (C) levels in healthy subjects (15 women and 15 men; duplicate assays) before running activity, immediately after running activity and $1 \mathrm{~h}$ after running activity. The results are expressed as median \pm IQR (interquartile range). $\quad * p<0.05 ; \quad * * p<0.01 ; \quad * * * p<0.001$ (compared to levels before running activity).

As for changes in the plasma levels of MDA, we found no significant difference after the physical exertion and after an hour of rest (Fig. 2A). MDA is a product of lipid peroxidation, which is a relatively slow process
(Yücel et al. 1998), and the resulting MDA immediately reacts with biomolecules within the cell, as indicated by the elevated levels of MDA in erythrocytes (Fig. 2B). It can also indicate increased oxidative stress in erythrocytes. Increased lipid peroxidation occurs in erythrocyte membranes due to an excessive production of ROS during exercise.

ANOVA was performed to examine the main effects of time (immediately and one hour after exercise), age, and interaction (time $\mathrm{x}$ age) on the measured variables (Table 2). There was significant main effect of time in the ANOVA of plasma allantoin (immediately after exercise), plasma UA (both immediately and one hour after exercise in men, one hour after exercise in women), plasma lactate (immediately after exercise), and red blood cells hemolysate (RBC) allantoin (both immediately and one hour after exercise), RBC UA (immediately after exercise) and RBC MDA (after one hour exercise). Effect of age in the ANOVA of plasma allantoin in women ( $\mathrm{p}=0.040$ and 0.022$), \mathrm{RBC}$ allantoin in men ( $p=0.016$ and 0.034$)$, plasma UA in men (0.031), RBC UA in women (0.049 and 0.045), plasma MDA (0.039) and RBC MDA (0.031 and 0.013) in women was observed, but statistically insignificant (power of test was $<0.800$ ). Traditionally, the power of the performed test should be $>0.8$.

\section{Discussion}

Current laboratory diagnostics of oxidative stress focuses on both the observation of the increased production of oxidants, disorders in antioxidant systems and monitoring of oxidative damage; and in recent years, the ability of the antioxidant system to adequately respond to oxidative stress (Kand'ár et al. 2007, Ogasawara et al. 2009, Dorjgochoo et al. 2012, Mesaros et al. 2012). Allantoin was recently suggested as an indicator of oxidative stress (Kand'ár et al. 2006, Kand'ár and Záková 2008a, Yardim-Akaydin et al. 2006, Gruber et al. 2009).

It was shown that skeletal muscle consumes UA during exercise (McAnulty et al. 2007). Waring et al. (2001) suggested the important antioxidant role of UA at exercise. UA levels in cells are replenished by uptake from blood after exercise (Hellsten et al. 2001). A significant relationship between plasma UA levels and acute oxidative stress during exercise was found (Mikami et al. 2000). 
Table 2. Summary table for the two factor analysis of variance (ANOVA) investigating the changes in levels of allantoin, uric acid, malondialdehyde and lactate in women and men as a function of time (immediately after exercise and one hour after exercise) and age.

\begin{tabular}{|c|c|c|c|c|c|c|c|c|c|}
\hline \multirow[b]{2}{*}{ Set } & \multirow[b]{2}{*}{ Factor } & \multicolumn{4}{|c|}{ Immediately after exercise } & \multicolumn{4}{|c|}{ One hour after exercise } \\
\hline & & $\mathbf{F}$ & $\mathbf{p}$ & $\begin{array}{c}\text { Power } \\
(1-\beta)\end{array}$ & Conclusion & $\mathbf{F}$ & $\mathbf{p}$ & $\begin{array}{c}\text { Power } \\
(1-\beta)\end{array}$ & Conclusion \\
\hline Women & Time & 221.460 & $<0.001$ & 1.000 & Significant & 3.245 & 0.097 & 0.269 & - \\
\hline$P \_A L A$ & Age & 3.061 & 0.040 & 0.558 & - & 3.642 & 0.022 & 0.686 & - \\
\hline$(\mu \mathrm{mol} / \mathrm{l})$ & Time*Age & 0.974 & 0.498 & 0.050 & - & 0.417 & 0.890 & 0.050 & - \\
\hline Men & Time & 92.857 & $<0.001$ & 1.000 & Significant & 0.742 & 0.406 & 0.050 & - \\
\hline$P \_A L A$ & Age & 0.925 & 0.529 & 0.0500 & - & 1.727 & 0.190 & 0.204 & - \\
\hline$(\overline{\mu m o l / l)}$ & Time*Age & 0.200 & 0.985 & 0.0500 & - & 0.110 & 0.998 & 0.050 & - \\
\hline Women & Time & 99.230 & $<0.001$ & 1.000 & Significant & 87.425 & $<0.001$ & 1.000 & Significant \\
\hline$R B C \_A L A$ & Age & 1.946 & 0.144 & 0.262 & - & 1.605 & 0.222 & 0.174 & - \\
\hline$(\mathrm{nmol} / \mathrm{g} \mathrm{Hb})$ & Time*Age & 0.379 & 0.912 & 0.050 & - & 0.433 & 0.879 & 0.050 & - \\
\hline Men & Time & 141.822 & $<0.001$ & 1.000 & Significant & 150.828 & $<0.001$ & 1.000 & Significant \\
\hline$R B C \_A L A$ & Age & 3.989 & 0.016 & 0.750 & - & 3.197 & 0.034 & 0.591 & - \\
\hline$(\mathrm{nmol} / \mathrm{g} \mathrm{Hb})$ & Time*Age & 0.739 & 0.658 & 0.050 & - & 0.666 & 0.712 & 0.050 & - \\
\hline Women & Time & 5.295 & 0.040 & 0.471 & - & 17.196 & 0.001 & 0.968 & Significant \\
\hline$P_{-} U A$ & Age & 0.779 & 0.629 & 0.050 & - & 0.834 & 0.591 & 0.050 & - \\
\hline$(\overline{\mu m o l / l)}$ & Time*Age & 0.009 & 1.000 & 0.050 & - & 0.026 & 1.000 & 0.050 & - \\
\hline Men & Time & 19.004 & $<0.001$ & 0.981 & Significant & 64.023 & $<0.001$ & 1.000 & Significant \\
\hline$P \_U A$ & Age & 2.820 & 0.052 & 0.498 & - & 3.289 & 0.031 & 0.612 & - \\
\hline$(\mu \mathrm{mol} / \mathrm{l})$ & Time*Age & 0.016 & 1.000 & 0.050 & - & 0.098 & 0.999 & 0.050 & - \\
\hline Women & Time & 25.551 & $<0.001$ & 0.997 & Significant & 6.558 & 0.025 & 0.580 & - \\
\hline$R B C U A$ & & 2.859 & 0.0 & 0.508 & - & 2.941 & 0.045 & 0.52 & - \\
\hline$(\mathrm{nmol} / \mathrm{g} \mathrm{Hb})$ & Time*Age & 0.106 & 0.998 & & - & 0.095 & 0.999 & 0.0 & - \\
\hline Men & Time & 12.672 & 0.004 & 0.893 & Significant & 4.185 & 0.063 & 0.364 & - \\
\hline$R B C \_U A$ & Age & 1.688 & 0.199 & 0.194 & - & 1.285 & 0.335 & 0.102 & - \\
\hline$(\mathrm{nmol} / \mathrm{g} \mathrm{Hb})$ & Time*Age & 0.061 & 1.000 & 0.050 & - & 0.036 & 1.000 & 0.050 & - \\
\hline Women & & & & & - & & & & - \\
\hline$P \_M D A$ & & 3.071 & 0.039 & 0.561 & - & 2.375 & 0.086 & 0.379 & - \\
\hline$(\overline{\mu m o l / l)}$ & Time*Age & 0.025 & 1.000 & 0.050 & - & 0.050 & 1.000 & 0.050 & - \\
\hline Men & Time & 0.173 & 0.685 & 0.050 & - & 0.409 & 0.534 & 0.050 & - \\
\hline$P \_M D A$ & Age & 1.300 & 0.329 & 0.105 & - & 1.097 & 0.427 & 0.066 & - \\
\hline$(\overline{\mu m o l} / l)$ & Time*Age & 0.004 & 1.000 & 0.050 & - & 0.015 & 1.000 & 0.050 & - \\
\hline Women & Time & & 0.523 & 0.050 & - & 40.915 & $<0.001$ & 1.000 & Significant \\
\hline$R B C \_M D A$ & Age & 3.312 & 0.031 & 0.617 & - & 4.238 & 0.013 & 0.789 & - \\
\hline (nmol/g Hb) & Time*Age & 0.037 & 1.000 & 0.050 & - & 0.030 & 1.000 & 0.050 & - \\
\hline Men & Time & 0.612 & 0.449 & 0.050 & - & 34.614 & $<0.001$ & 1.000 & Significant \\
\hline$R B C \_M D A$ & Age & 1.730 & 0.189 & 0.205 & - & 2.268 & 0.097 & 0.349 & - \\
\hline$(\mathrm{nmol} / \mathrm{g} \mathrm{Hb})$ & Time*Age & 0.020 & 1.000 & 0.050 & - & 0.094 & 0.999 & 0.050 & - \\
\hline Women & Tim & 82.520 & $<0.001$ & 1.000 & Significant & 0.861 & 0.372 & 0.050 & - \\
\hline$P_{\text {LLactate }}$ & Age & & & & - & 0.823 & 0.598 & 0.050 & - \\
\hline$(\mathrm{mmol} / \mathrm{l})$ & Time*Age & 0.236 & 0.967 & 0.050 & - & 0.024 & 1.000 & 0.050 & - \\
\hline Men & Time & 104.457 & $<0.001$ & 1.000 & Significant & 4.086 & 0.066 & 0.354 & - \\
\hline$P$ Lactate & Age & 1.217 & 0.366 & 0.088 & - & 1.392 & 0.292 & 0.124 & - \\
\hline$(\overline{m m o l} / \mathrm{l})$ & Time*Age & 0.554 & 0.796 & 0.050 & - & 0.019 & 1.000 & 0.050 & - \\
\hline
\end{tabular}

The $\mathrm{F}$ test statistic is provided for comparisons within each factor and between the factors. The $\mathrm{p}$ value is the probability of being wrong in concluding that there is a true difference between the groups. There are significant differences if $p<0.05$. The Power or sensitivity is the probability that the test will detect the observed difference among the groups if there really is a difference. The closer the power is to 1 , the more sensitive the test. Traditionally, the power of the performed test should be $>0.8$. Less than desired power indicates you are less likely to detect a difference when one actually exists. Negative results should be interpreted cautiously. P - Plasma, RBC - Red Blood Cells, ALA - Allantoin, UA - Uric Acid, MDA - Malondialdehyde. 
Many studies showed that UA is oxidized by ROS mainly to allantoin (Matrens et al. 1987, Santos et al. 1999, Kand'ár and Záková 2008a). Oxidation of UA to allantoin during exercise suggests both that UA is of significant as an antioxidant and that ROS are formed (Hellsten et al. 2001). Therefore UA and allantoin levels as well allantoin/UA ratio are suitable indicators in the assessment of the level of acute oxidative stress in human during exercise.

Hellsten et al. (1997) found a physiological increase in allantoin levels in the plasma of 7 voluntary blood donors, who performed five minutes of intense exercise. They state that these volunteers had allantoin concentrations in the range of $11.9 \pm 2.6 \mu \mathrm{mol} / 1$ before exercise, and during exercise the concentration more than doubled. The level of UA in plasma rose from $305 \pm 16 \mu \mathrm{mol} / 1$ to $426 \pm 20 \mu \mathrm{mol} / 1$ within $45 \mathrm{~min}$ after the exercise. We achieved similar results, but with a much higher variance in the measured levels. They also compared the levels of allantoin and UA directly in muscles and obtained the following results: the UA level in muscle tissue decreased from $0.260 \pm 0.023 \mu \mathrm{mol} / \mathrm{g}$ to $0.084 \pm 0.016 \mu \mathrm{mol} / \mathrm{g}$ during exercise and then increased sharply during the first three minutes after exercise. The allantoin concentration increased from $0.030 \pm 0.007$ $\mu \mathrm{mol} / \mathrm{g}$ to $0.100 \pm 0.014 \mu \mathrm{mol} / \mathrm{g}$ during exercise and it decreased to $0.079 \pm 0.002 \mu \mathrm{mol} / \mathrm{g}$ during the first three minutes after exercise. Muscle biopsy is an invasive intervention, so a simpler way needed to be found to monitor oxidative stress in cells during physical exertion. Erythrocytes seemed to be suitable cells.
It is generally known that oxidative stress markers are age-depended. Some indications were observed; on the other hand the power of the performed tests was below the desired power of 0.800 . ANOVA power is affected by the sample size. Furthermore, a small age difference (14 years in women and 19 years in men) is in the study group.

It can be concluded that the importance of ROS in sports is not yet fully appreciated and influencing the production and effects of ROS might be a way to improve the performance of athletes. Our results suggest that during sports activities, the levels of allantoin and UA in plasma and erythrocytes are increased. UA is probably oxidized by ROS to allantoin. Our study based on the monitoring of UA and allantoin levels in plasma and erythrocytes during 10-min running activity reveal that allantoin may be suitable candidate for a marker of acute oxidative stress. Determination of allantoin levels in erythrocytes is for the monitoring of an acute oxidative stress more suitable because plasma allantoin is rapidly and completely eliminated via the kidneys. In addition, whole blood is more available biological material than a biopsy sample.

\section{Conflict of Interest}

There is no conflict of interest.

\section{Acknowledgements}

This work was supported by Grant SGFChT07/2013 from the Czech Ministry of Education.

\section{References}

ABDUL-RASHEED OF, FARID YY, AL-NASIRI US: Coenzyme Q10 and oxidative stress markers in seminal plasma of Iraqi patients with male infertility. Saudi Med J 31: 501-506, 2010.

AMES BN, CATHCART R, SCHWIERS E, HOCHSTEIN P: Uric acid provides an antioxidant defense in humans against oxidant- and radical-caused aging and cancer: a hypothesis. Proc Natl Acad Sci USA 78: 6858-6862, 1981.

BECKER BF: Towards the physiological function of uric acid. Free Radic Biol Med 14: 615-631, 1993.

BECKER BF, REINHOLZ N, LEIPERT B, RASCHKE P, PERMANETTER B, GERLACH E: Role of uric acid as an endogenous radical scavenger and antioxidant. Chest 100: 176S-181S, 1991.

BERTHEMY A, NEWTON J, WU D, BUHRMAN D: Quantitative determination of an extremely polar compound allantoin in human urine by LC-MS/MS based on the separation on a polymeric amino column. $J$ Pharm Biomed Anal 19: 429-434, 1999.

CASTROGIOVANNI P, IMBESI R: Oxidative stress and skeletal muscle in exercise. Ital J Anat Embryol 117: 107-117, 2012. 
CHUNG WY, BENZIE IF: Plasma allantoin measurement by isocratic liquid chromatography with tandem mass spectrometry: method evaluation and application in oxidative stress biomonitoring. Clin Chim Acta 424: 237-244, 2013.

DORJGOCHOO T, GAO YT, CHOW WH, SHU XO, YANG G, CAI Q, ROTHMAN N, CAI H, LI H, DENG X, FRANKE A, ROBERTS LJ, MILNE G, ZHENG W, DAI Q: Major metabolite of F2-isoprostane in urine may be a more sensitive biomarker of oxidative stress than isoprostane itself. Am J Clin Nutr 96: 405-414, 2012.

GIUSTARINI D, DALLE-DONNE I, TSIKAS D, ROSSI R: Oxidative stress and human diseases: origin, link, measurement, mechanisms, and biomarkers. Crit Rev Clin Lab Sci 46: 241-281, 2009.

GRAVIER G, STEINBERG JG, LEJEUNE PJ, DELLIAUX S, GUIEU R, JAMMES Y: Exercise-induced oxidative stress influences the motor control during maximal incremental cycling exercise in healthy humans. Respir Physiol Neurobiol 186: 265-272, 2013.

GRUBER J, TANG SY, JENNER AM, MUDWAY I, BLOMBERG A, BEHNDIG A, KASIMAN K, LEE CY, SEET RC, ZHANG W, CHEN C, KELLY FJ, HALLIWELL B: Allantoin in human plasma, serum, and nasal-lining fluids as a biomarker of oxidative stress: avoiding artifacts and establishing real in vivo concentrations. Antioxid Redox Signal 11: 1767-1776, 2009.

HELLSTEN Y, TULLSON PC, RICHTER EA, BANGSBO J: Oxidation of urate in human skeletal muscle during exercise. Free Radic Biol Med 22: 169-174, 1997.

HELLSTEN Y, SVENSSON M, SJÖDIN B, SMITH S, CHRISTENSEN A, RICHTER EA, BANGSBO J: Allantoin formation and urate and glutathione exchange in human muscle during submaximal exercise. Free Radic Biol Med 31: 1313-1322, 2001.

HICKS M, WONG LS, DAY RO: Identification of products from oxidation of uric acid induced by hydroxyl radicals. Free Rad Res Comms 18: 337-351, 1993.

IL'YASOVA D, SCARBROUGH P, SPASOJEVIC I: Urinary biomarkers of oxidative status. Clin Chim Acta 413: 1446-1453, 2012.

JI LL: Antioxidants and oxidative stress in exercise. Proc Soc Exp Biol Med 222: 283-292, 1999.

KANĎÁR R, ZÁKOVÁ P: Allantoin as a marker of oxidative stress in human erythrocytes. Clin Chem Lab Med 46: 1270-1274, 2008a.

KANĎÁR R, ZÁKOVÁ P: Determination of ascorbic acid in human plasma with a view to stability using HPLC with UV detection. J Sep Sci 31: 3503-3508, 2008 b.

KANĎÁR R, MUZÁKOVÁ V, CEGAN A: Highly specific, simple and rapid method for the determination of malondialdehyde in blood using high-performance liquid chromatography. Clin Chem Lab Med 40: 1032$1035,2002$.

KANĎÁR R, ZÁKOVÁ P, MUZÁKOVÁ V: Monitoring of antioxidant properties of uric acid in humans for a consideration measuring of levels of allantoin in plasma by liquid chromatography. Clin Chim Acta $\mathbf{3 6 5}$ : 249-256, 2006.

KANĎÁR R, ZÁKOVÁ P, LOTKOVÁ H, KUCERA O, CERVINKOVÁ Z: Determination of reduced and oxidized glutathione in biological samples using liquid chromatography with fluorimetric detection. J Pharm Biomed Anal 43: 1392-1397, 2007.

KANEKO K, KIMATA T, TSUJI S, OHASHI A, IMAI Y, SUDO H, KITAMURA N: Measurement of urinary 8-oxo7,8-dihydro-2-deoxyguanosine in a novel point-of-care testing device to access oxidative stress in children. Clin Chim Acta 413: 1822-1826, 2012.

KAUR H, HALLIWELL B: Action of biologically-relevant oxidizing species upon uric acid. Identification of uric acid oxidation products. Chem Biol Interact 73: 235-247, 1990.

LAGENDIJK J, UBBINK JB, VERMAAK WJH: The determination of allantoin, a possible indicator of oxidant status, in human plasma. J Chromatogr Sci 33: 186-193, 1995.

MAPLES KR, MASON RP: Free radical metabolite of uric acid. J Biol Chem 263: 1709-1712, 1988.

MATRENS ME, STOREY BT, LEE CP: Generation of allantoin from the oxidation of urate by cytochrome c and its possible role in Reye's syndrome. Arch Biochem Biophys 252: 91-96, 1987. 
MCANULTY SR, HOSICK PA, MCANULTY LS, QUINDRY JC, STILL L, HUDSON MB, DIBARNARDI AN, MILNE GL, MORROW JD, AUSTIN MD: Effect of pharmacological lowering of plasma urate on exerciseinduced oxidative stress. Appl Physiol Nutr Metab 32: 1148-1155, 2007.

MESAROS C, ARORA JS, WHOLER A, VACHANI A, BLAIR IA: 8-Oxo-2'-deoxyguanosine as a biomarker of tobacco-smoking-induced oxidative stress. Free Radic Biol Med 53: 610-617, 2012.

MIKAMI T, YOSHIDO Y, ITO T: Does a relationship exist between the urate pool in the body and lipid peroxidation during exercise. Free Radical Res 32: 31-39, 2000.

OGASAWARA Y, FUNAKOSHI M, ISHII K: Determination of reduced nicotinamide adenine dinucleotide phosphate concentration using high-performance liquid chromatography with fluorescence detection: ratio of the reduced form as a biomarker of oxidative stress. Biol Pharm Bull 32: 1819-1823, 2009.

RAMOS D, MARTINS EG, VIANA-GOMES D, CASIMIRO-LOPES G, SALERNO VP: Biomarkers of oxidative stress and tissue damage released by muscle and liver after a single bout of swimming exercise. Appl Physiol Nutr Metab 38: 507-511, 2013.

SANTOS CX, ANJOS EI, AUGUSTO D: Uric acid oxidation by peroxynitrite: multiple reactions, free radical formation, and amplification of lipid peroxidation. Arch Biochem Biophys 372: 285-294, 1999.

SCHRAG M, MUELLER C, ZABEL M, CROFFON A, KIRSCH WM, GHRIBI O, SQUITTI R, PERRY G: Oxidative stress in blood in Alzheimer's disease and mild cognitive impairment: a meta-analysis. Neurobiol Dis 59: 100-110, 2013.

TOLUN AA, ZHANG H, IL'YASOVA D, SZTÁRAY J, YOUNG SP, MILLINGTON DS: Allantoin in human urine by ultra-performance liquid chromatography-tandem mass spectrometry. Anal Biochem 402: 191-193, 2010.

TOLUN AA, SCARBROUGH PM, ZHANG H, MCKILLOP JA, WANG F, KISHANI PS, MILLINGTON DS, YOUNG SP, IL'YASOVA D: Systemic oxidative stress, as measured by urinary allantoin and $\mathrm{F}(2)$ isoprostanes, is not increased in Down syndrome. Ann Epidemiol 22: 892-894, 2012.

TURNER R, STAMP LK, KETTLE AJ: Detection of allantoin in clinical samples using hydrophilic liquid chromatography with isotope dilution negative ion tandem mass spectrometry. $J$ Chromatogr B 891-892: 85-89, 2012.

VOLK KJ, YOST RA, BRAJTER-TOTH A: On-line electrochemistry/thermospray/tandem mass spectrometry as a new approach to the study of redox reactions: the oxidation of uric acid. Anal Chem 61: 1709-1717, 1989.

WARING WS, WEBB DJ, MAXWELL SR: Systemic uric acid administration increases serum antioxidant capacity in healthy volunteers. J Cardiovasc Pharmacol 38: 365-371, 2001.

YARDIM-AKAYDIN S, SEPICI A, OZKAN Y, SIMŞEK B, SEPICI V: Evaluation of allantoin levels as a new marker of oxidative stress in Behçet's disease. Scand J Rheumatol 35: 61-64, 2006.

YELDANDI AV, PATEL YD, LIAO M, KAO FT, RAO MS, REDDY JK, LE BEAU MM: Localization of the human urate oxidase gene (UOX) to 1p22. Cytogenet Cell Genet 61: 121-122, 1992.

YÜCEL D, AYDOĞDU S, ÇEHRELI S, SAYDAM G, CANATAN H, ŞENEŞ M, ÇIĞDEM TOPKAYA B, NEBIOĞLU S: Increased oxidative stress in dilated cardiomyopathic hearth failure. Clin Chem 44: 148-154, 1998. 